\title{
CRM AS A SUPPORT FOR KNOWLEDGE MANAGEMENT AND CUSTOMER RELATIONSHIP
}

\author{
Silvana Toriani \\ University of Southern Santa Catarina, Brazil \\ Maria Terezinha Angeloni \\ Pierre Mendès France University, France
}

\begin{abstract}
This paper aims to analyze the role of Customer Relationship Management (CRM) as a support for Knowledge Management (KM) and the Customer Relationship Strategy Definition in an Information Technology (IT) Company. This work is based on theories of KM, IT, and Relationship Marketing. Our survey uses a descriptive approach, in which data is gathered by means of content analysis of semi-structured interviews. The study results have shown us that the company implements an effective system for CRM, in which the system users transform data into information and knowledge in order to support decision-making and strategy definition.
\end{abstract}

Keywords: Customer Relationship Management, Knowledge Management, Relationship Marketing, and Customer Relationship Strategy.

Recebido em/Manuscript first received: 16/03/2009 Aprovado em/Manuscript accepted: 23/07/2010

Endereço para correspondência/ Address for correspondence

Silvana Toriani, Master in Business Administration from the University of Southern Santa Catarina Professor and coordinator of the Senac Commercial Management Course Rua: Silva Jardim, 360, Cep: 88020 -200 - Prainha - Florianópolis Phone: 489119 0635; 483229 3247/ Fax 483229 3215 E-mail: siltoriani@yahoo.com.br

Maria Terezinha Angeloni, $\mathrm{PhD}$ in Business Administration from the Pierre Mendès France University -Grenoble, France; Professor and researcher in Knowledge Management Phone: 48 - 99691020 E-mail: angelggc@hotmail.com

ISSN online: $1807-1775$

Publicado por/Published by: TECSI FEA USP - 2011 


\section{INTRODUCTION}

In Brazil, the opening of borders and the process of globalization have more effectively happened since 1990, when the fierce competition and the constant changes meant that organizations had to adopt new forms of management. The changes that have contributed to the organizational development emphasized the importance of the human element in the organization: it is the passage from the second to the third wave, cited by Toffler (1980), i.e. from the industrial wave to a wave of information and knowledge.

In the second wave, the competitive advantage was obtained by means of the location and access to cheap labor, natural resources and the financial capital, and in the third one, the management of information and knowledge, the use of Information Technology and the relationship with the customer are considered important factors in organizational performance and they result in obtaining a competitive advantage.

Vera and Crossan (2005), besides addressing how knowledge becomes a sustainable competitive advantage, they study the process by which it is created, developed, stored and transferred in a constant cycle of processing of data into information and information into knowledge according to Smit and Talamo (2007).

Therefore, managing knowledge and relating to customers seeking their loyalty have become one of the prerogatives for the organizations that want to survive the competition. It is notably observed that companies are faced with the challenge of competing in a world where knowledge adds value to organizations being considered by Wiig (1997), Hansen, Nohria and Tierney, (1999), as the fourth factor of production, with superior pertinence to traditional land, labor and capital.

Based on the foregoing, this study seeks to examine the role of CRM as a support for Knowledge Management and to develop strategies of relationship with the customer, based on the assumption that they are determining factors for organizations that wish to have quality and fast delivery of products and services to customers. Consequently it is necessary to know how CRM can be used to generate knowledge and to support strategies of customer relationship.

To achieve the proposed objective, the article is structured from this introduction, followed by theoretical assumptions that underlie the study, the methodology and data analysis. In the final considerations, the main results and reflections on the study are presented.

\section{2 . THEORETICAL FRAMEWORK}

The study is supported on three theoretical foundations: Knowledge Management-KM, Technologies Customer Relationship, and Relationship MarketingRM. 


\subsection{CRM as a knowledge management support}

Knowledge Management (KM) is not considered as a new practice by authors such as Hansen, Nohria and Tierney (1999). For them, new is the "aware" practice of Knowledge Management in organizations. Davenport and Prusak (1998) also believe that, even before this subject matter became commonplace, good managers already valued the experience and the know-how of their employees, that is, their knowledge. According to Sveiby (1998, p. 3), "Knowledge Management is no longer a fashion of operational efficiency. It is part of the corporate strategy ", which leads to think about Knowledge Management as a strategy.

The interest in KM has generated countless scientific and practical work. They can be classified into two approaches, the functionalist and the interpretative. The first approach emphasizes the explicit knowledge, treating it as a manageable "object" (Dhaliwal; Benbasat, 1996; Gregor; Benbasat, 1999; Zhao; Kumar; Stohr, 2001). The authors dealing with Knowledge Management in the functionalist perspective aim to create ways to disseminate and expand the knowledge from the support of different technologies (Easterby-Smith; Lyles, 2005). The second approach emphasizes the tacit knowledge, treating it as a "process" (George; Iacono; Kling, 1995; Schultze; Boland, 2000; Stenmark, 2001; Von Krogh; Ichijō; Nonaka, 2001; Alvarenga Neto, 2010; Cassapo, 2009).

The authors dealing with $\mathrm{KM}$ in an interpretative perspective must focus on people and consequently in building an environment of interaction between individuals through the creation of "Ba", which can be interpreted according to Nonaka and Konno (1998) as space, or context, shared for new relationships.

Therefore, when speaking about Knowledge Management there are the two types, the explicit and the tacit, considered by Polanyi (1998) as parts of a cycle in which the person gets explicit knowledge, incorporates and uses it such as tacit, and generates new explicit knowledge, which can be absorbed by another person.

Based on the assumption that the creation of knowledge occurs through interaction of tacit knowledge with the explicit, Nonaka and Takeuchi (1997) postulated four modes of conversion of knowledge into a business, creating what he termed as "spiral of knowledge". The modes are: socialization (from tacit to tacit); outsourcing (from tacit to explicit); combination (from explicit to explicit); and internalization (from explicit to tacit).

Aiming to support the spiral of knowledge, Rodriguez y Rodriguez (2002, p. 122) present some technologies related to modes of conversion of knowledge as in table 1. 


\begin{tabular}{l|l|l}
$\begin{array}{l}\text { From: } \\
\text { Tacit Knowledge }\end{array}$ & $\begin{array}{l}\text { Socialization } \\
\text { Knowledge maps }\end{array}$ & $\begin{array}{l}\text { Externalization } \\
\text { Groupware } \\
\text { Workflow } \\
\text { Intelligent bases of } \\
\text { Knowledge } \\
\text { CRM }\end{array}$ \\
\hline $\begin{array}{l}\text { From: } \\
\text { Knplicit }\end{array}$ & $\begin{array}{l}\text { Internalization } \\
\text { Innovation support } \\
\text { Combination } \\
\text { CRM } \\
\text { Intranet } \\
\text { Electronic Management } \\
\text { of Documents } \\
\text { Business Intelligence }\end{array}$
\end{tabular}

Table 1 - Knowledge training

Source: Rodriguez y Rodriguez (2002, p. 122)

Analyzing the frame, we can observe the presence of CRM as a technology support to the outsourcing of knowledge, which can be exemplified by the explicitation of tacit knowledge about customers and the person who is just in the minds of the employees who have contact with them. As CRM is powered, knowledge becomes explicit and may be used by other industries or employees who require data and information about the customer.

CRM also supports the combination of explicit knowledge, because an explicit knowledge can be used in conjunction with other explicit knowledge such as rules or standards of the company in dealings with customers, number of contacts, operations, purchased products, etc., forming new knowledge.

Therefore, one can conclude that CRM supports two forms of conversion of knowledge presented by Nonaka and Takeuchi (1997), namely the outsourcing and the combination.

All the arguments presented so far have the goal to demonstrate the dynamics of the transformation of supplied or made available data by the technological CRM tool in information and knowledge that could be used by organizations. This will become a benefit as a whole only when the technological tools are used to the fullest and when knowledge is transformed from tacit into explicit and vice versa, disseminated, transferred, shared and applied to organizational activities.

\section{2 .2 CRM-information technologies to support customer management}

Contemporary management models have been benefited from the development of Information Technology. Among the many changes offered by the technological progress is the development and improvement of databases on customers. Improvement because you can search, in the recent past, management practices carried out manually, through notebooks, binders, and request blocks. Fortunately there are a variety of 
technologies and software to manage the relationship with customers and Zenone (2010) highlights that CRM is not exclusively a technology, or "just a software application", noting that the technology is important to enable the deployment of CRM but it does not guarantee success or failure of implementation.

In the same sense, Richers (2000, p. 105) considers that CRM extends beyond a technology. To the author, CRM is a business strategy designed to increase the profitability and the company's revenue through the increased level of satisfaction of those who use the goods and services marketed by it. "

Gummesson $(2009$, p. 23) states that "CRM are the values and strategies of MRwith special emphasis on the relationship between the customer and suppliertransformed into practical application and dependent on human action and Information Technology."

Scott (2001, p. 2) adds,

CRM is a business strategy focused on the understanding and anticipating the needs of present and future customers of a company. From a technology perspective, it involves capturing customer data throughout the enterprise, consolidates all data captured internally and externally in a central database, analyzes the consolidated data, distributes the results of such an analysis to the various points of customer contact and uses this information by interacting with the customer through any point of contact with the company.

The inputs to the implementation of this strategy focused on the customer are the transformation of data into information management; such a process was facilitated by the development of Information Technologies. Under this perspective, CRM is a process that searches for customer data and transforms them into relevant and up-to-date information to support relationships, generating knowledge.

Teixeira (2003) states that the key point of efficiency is the use and integration of knowledge and relationship models (CRM, BI - Business Intelligence, and KM Knowledge Management) that give companies valuable information and guide decisionmaking and strategic settings by providing timely and accurate information about customers' consumption habits. This is one of the reasons why CRM should be integrated into all actions of the company, providing the costumer with agility and reliability.

CRM is not a product or service, i.e. it does not bring profits directly; it serves as a business strategy to manage the relationship with the customer in the search for the maintenance and retention of the relatioship, generating long-term and indirect results. For this strategy to be successful, according to Norris and Hurley (2001), the company must take into account a set of variables, because its implementation requires skilled people, well-defined processes, cultural changes and new attitudes from the employees with regard to the data supply in the system. Kotler and Armstrong (2007) add that CRM should involve the management of detailed information about customers. For the implementation of CRM, Peppers and Rogers (2001, p. 28-31) propose four steps. The first consists in identifying each customer by the company, as a prerequisite, since each customer requires a different type of relationship.Thus, the acquisition of customer knowledge to start a relationship becomes imperative. The second consists of the differentiation of customers by value and by needs. The purpose of differentiation is 
to identify customers of most value (CMV) and with the costumers of most potential (CMP), to develop a long-term relationship with the more profitable ones. As for interaction, the third stage occurs after the identification of the CMVs and the CMPs. The fourth and last step is customization. After getting the data in relation to the needs of customers, it is up to the company to customize the services and products offered.

The four steps to CRM implementation demonstrate the importance of knowing the customer, to distinguish them better to meet their needs, to interact to create a relationship with them and to customize products, services and the care to retain the costumer. This model of CRM implementation is complete and enables the companies to contemplate the customer holistically.

For Peppers and Rogers (2000, 2001), companies can use, depending on their needs, one or more types of CRM. Operational CRM is the application of Information Technology to improve the efficiency of company-customer relationship, and it should include the integration of back office with mobile or virtual office. Collaborative CRM covers the main forms of contact with the customer of all areas of the company. The forms of contact must be prepared to ensure the adequate flow of data across the organization. Analytical CRM is the source of all the process' intelligence, being used to adjust the strategies of differentiation of customers, as well as for the monitoring of their habits. It uses analysis tools, data mining, and analytic reports that have as data source the data warehouse. The concept of data warehouse arose from the need to integrate business data spread across different platforms and operating system environments to make them accessible to all decision-making levels users (FELISONI, 2004, p. 97). For Stone, Woodcock, and Machtynger (2001, p. 228), "Data warehouse and data mining are not purposes themselves, but evidence to support the development of strategies and more competitive operations ".

Based on the types of CRM and the concept of conversion modes of knowledge in organizations, operational CRM aims to capture tacit customer data, which implies in its outsourcing of the organization. Currently, these given data will be analyzed by analytical CRM, combining them with other existing data in the organization. From this systematization, there is the need to socialize them by the Organization, through the Collaborative CRM.

Finally, after their socialization, this knowledge is internalized reaching its competitive differentiator. The primary goal of the adoption of three types of CRM in an integrated way is to streamline and optimize business processes. However, to be aligned with CRM it is necessary that the center of the data model be the customer and not the product, as in conventional processes and until now prevailing within organizations.

\subsection{Relationship marketing}

The companies' relationship with their customers has gained importance in the world business. The trend in the $21^{\text {st }}$ century, according to Boone \& Kurtz (1998) and Rapp \& Collins (1996), is that the company understands the need of its customer and manage the relationship, what to Bretzke (2000) means "care and caring" relationship. 
Relationship Marketing according to Dias (2003) is a strategy that aims to build a lasting relationship between customer and supplier, based on trust, collaboration, commitment, partnership, investment and mutual benefits, resulting in returning optimization to the company and its customers.

For Schultz, Tannenbaum and Lauterborn (1994), since the companies and customers learn more with each other through various forms of interplay and communication systems, the integration of marketing communications occurs naturally. Individualized marketing communication is the key factor in the relationship between the customer and the organization, since, if this process fails, the customer will certainly cut this link.

Contemporary organizations prioritize best management practices and communication to optimize the relationship with customers. This form of desired relationship transcends the simple relationship marketing and aims to know the customer fully to meet their needs, expectations and to establish lasting bonds.

Kotler \& Armstrong (2007) highlight the importance of continued involvement of members of the organization with each of its customers and in particular with the best customers in order to serve them with excellence, not combining, according to Rapp and Collins (1996), with short-term thinking.

According to the authors, years of work can be destroyed in a moment by organizations with immediate vision. Kotler and Armstrong (2007) stress that building lasting relationships is the key to the creation of superior values and satisfaction for the customer, and satisfied customers are more likely to become loyal customers. Mckenna (1993) supports this argument and adds that creating solid and lasting relationships is an arduous task, difficult to maintain in a world where the customer has so many options that a personal relationship is the only way to keep them loyal.

Lovelock (2005, p. 150) considers loyalty as a "voluntary decision of a customer to continue supporting a specific company during an extended period." However, this loyalty, according to the author, cannot be taken for granted, because the customer only remains loyal to the company while he thinks that he is getting the best price in relation to quality, otherwise he will be open to change suppliers; but, for Zenone (2010), if the company creates intimacy with the customer and knows him deeply, the tendency is the unwillingness to seek new suppliers.

D'Angelo, Schneider and Laran (2006) emphasize that for the adoption of Relationship Marketing, the Company must be mature, full of ideals and commitment to certain principles that are regarded as fundamental to the business success, as part of its plan of action, and then it will engage in choosing and format the resources needed for the MR implementation. The authors highlight the importance of a customerfocused culture, which is complemented by Zenone (2010) by highlighting the relevance of variables, processes, people and technologies focused on Customer Relationship Management, making MR a style of doing business.

Thus, it is up to the marketing strategist, to define strategies based on the analysis of these variables, for which the expected targets are effectively met. The ideal situation is that companies that get support from the relationship with the customer as a 
business strategy and that use both technological tools such as CRM go without neglecting the importance of empowering people to use generating knowledge and act strategically to maintain and build lasting relationships. Talking about relationship is the same as talking about loyalty, which consists of a big challenge for organizations, but the biggest challenge is to succeed to apply these concepts and gain competitive advantage.

\section{SURVEY RESEARCH METHOD}

The reasearcher needs a method as a guide to perform scientific research, which must indicate the steps to be followed in the process.

This survey is characterized as a case study with a descriptive main focus. For Franco (1986) and Godoy (1995), a case study is indicated when you want to portray a certain situation or unit and, subsequently, to make an analysis of this situation. In this survey, the unit to be studied is an Information Technology Company, located in Florianópolis, Brazil.

Sellitz (1987) classifies the survey research according to the type of knowledge that can be achieved depending on the object to be investigated: exploratory, descriptive, and causal. The descriptive model used in the study provides a preliminary knowledge base and aims to describe the characteristics of the object, seeking to list and explain what was really found.

The sample is composed of the President, three Vice Presidents and the subordinates of the Vice Presidency of Commercial Marketing (three directors, three managers, and three supervisors) in a total of 13 (thirteen) respondents who account for 15 (fifteen) positions, because the President also reports to a Vice President and the Vice President of Business Marketing reports to a Board of Directors. Both occupy two positions of different levels. The definition of the sample was intentional and involved all offices that participate in strategic decision-making within the company and the directors, managers and supervisors who take care of the customer. According to Richardson (1989), the intentional sample is one in which participants are selected according to certain characteristics provided by the researcher, as in the case of this study.

The primary data were collected through semi structured interviews and direct observation and secondary data through documentation, records, files, databases, and bibliographic research. The interviews were recorded and performed in August and September 2008. After transcription, they passed through content analysis, which according to Bardin (1979) cannot be based on an exact model, following some rules of interpretation of different directions in the accounts. 


\section{DATA ANALYSIS}

Company characterization - the study was conducted in an Information Technology Company, founded in 1977. The head office located in Florianópolis in the State of Santa Catarina, focuses its activities on manufacturing and developing telecommunications solutions through $100 \%$ national high-tech.

It counts with the presence of 498 employees, of whom 334 (three hundred and thirty four) perform their activities in the haed office and the other employees are in regional offices located in São Paulo and Ribeirão Preto, in the State of São Paulo, Rio de Janeiro,in the State of Rio de Janeiro, Brasília - Federal District, Recife, in the State of Pernambuco, Curitiba, in the State of Paraná, Porto Alegre, in the State of Rio Grande do Sul, and São José, in the State of Santa Catarina.

The commercial and marketing Vice Presidency is characterized by a conglomerate of diverse knowledge, such as technical expertise, commercial, legal and administrative, and mainly data about customers. To generate these findings, the team uses a variety of information provided by various sectors within the organization itself, regional offices and affiliates, in addition to the database about customers. The database about customers is a multifunctional system, called TICO, developed by the company. TICO can be characterized as a large database where all customer information is stored. TICO structure is composed by sub-systems, as shown in Figure 1.

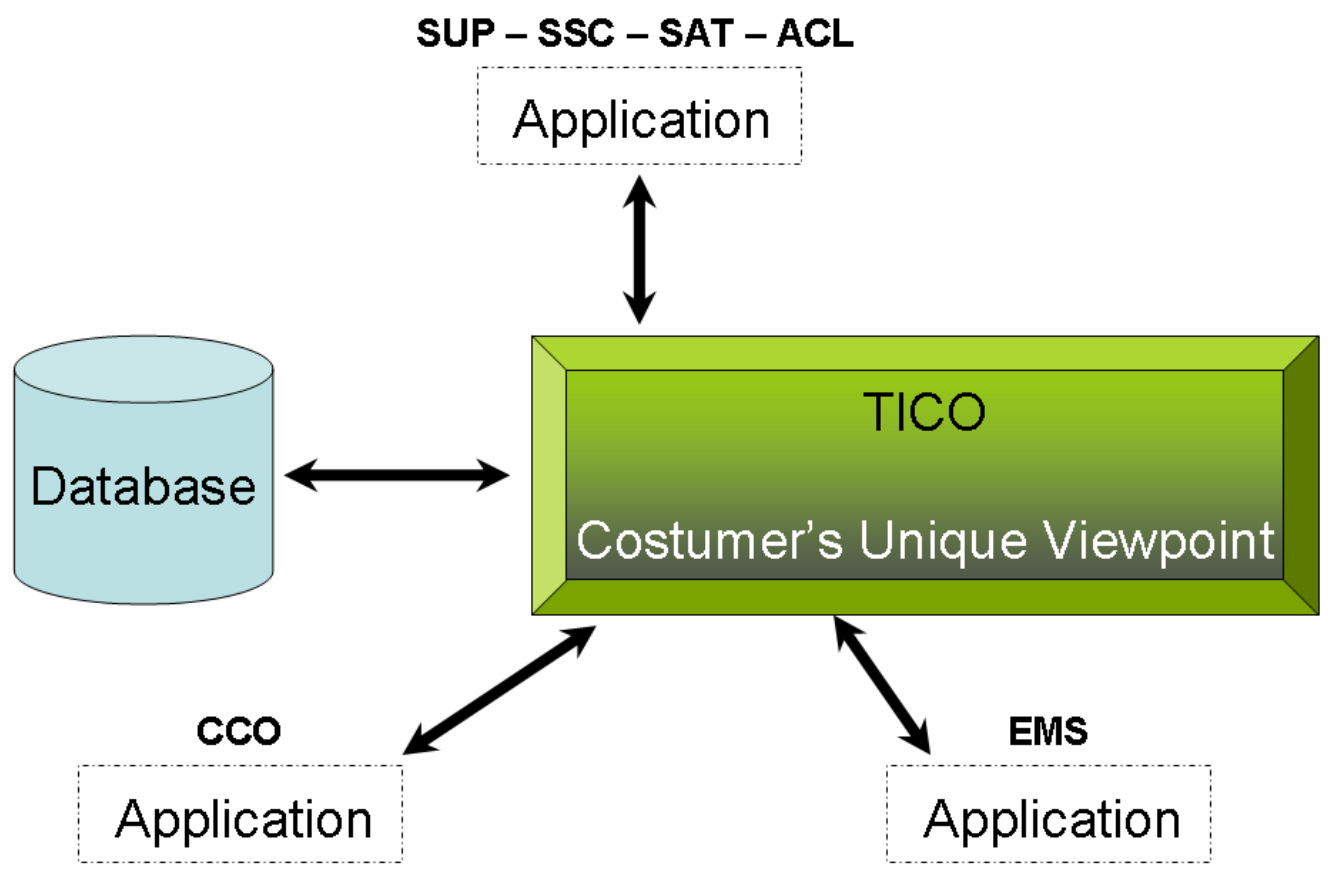

Figure 1 - Presentation of TICO and Information Technology Company subsystems Source: Company documents

SUP: Technical support management.

ACL: Customer monitoring. 
SSC: Call service center support.

SAT: Technical assistance service.

CCO: Commercial contracts.

EMS: Costumer's personal and financial data.

The system was developed to meet the needs of the customer service in light of the particularity of marketed products and services. The company does not sell commodities, it sells a tailored communication solution; therefore, it needs an effective and complete database on the customer. To ensure reliability and perfect functioning of that system, all employees have passwords and login to access subsystems in which all daily activities related to the customer are recorded.

After the characterization of the company studied and the presentation of the relationship with the customer, we pass on to the results of the goals aimed at.

The first of the specific objectives of this study "aims to understand the usage of CRM in customer relationship management."

In order to answer it respondents were questioned about what customer relationship technological tool the company uses:

V1 - Yes, it has been 10 years of investment in this tool that is fantastic and TICO that was built for us.

V2 - (....) we are currently upgrading the system to adapt it as business as needs increase.

D3 - The information about the customer are in TICO, this is our CRM.

G3 - The Company works with its own software called TICO developed by the company's analysts. TICO is a melting pot of customer's information.

Based on data we can infer that the company has a technological tool called TICO, developed by the company itself and that contains all the customers' data. Recalling everything that was substantiated by CRM, we can affirm that the studied company has a technology base that addresses the customer with the concept of Cruz (1998) that calls CRM computerized technology support for cooperative work.

What was substantiated as an ideal CRM is not only to have a technological tool for data storage, but to have the database to use effective relationship with the customer.

Respondents were asked about the use of CRM, and we got the following answers:

V4 - We use TICO whenever we need to have contact with customers; in the customer base we have all the contact with the customers - whether they called or whether the after-sales service contacted them. The after-sales sometimes identifies new needs solutions that end up generating new business (...).

G2 - TICO is used to meet customer demands, as we sell custom solutions, our system 
has more than just the function of accumulating customer's point; it is the database that develops new solutions for the customer.

S3 - This is our system where any activity, any record, any action to be done, I have everything within that system (...)

The answers to this question demonstrate agreement with concepts of Pepper and Rogers (2001) who claim that when focus is on the customer, each customer is unique and as such the customer needs to be dealt with individual and two-way communications.

Respondents were asked aboutAs for the type of data that are obtained by means of the tool, we got these answers:

V4 - On TICO I got everything that happened with the customer, from the moment they were potential customers to the moment they became actual customers, I have the whole history, all contacts, financial situation, I know if I can offer a new solution ... everything.

D2 - When you enter into the customers' environment everything is there, the strategic importance for the company, the frequency value, financial situation, customer satisfaction, all the history that they have had with us, all of the contacts they have had with us, contracts (...)

It is noticeable the importance of the system to work in the company, the type of business suggests the personalized service to customers. TICO is the system used by the Company in relationship with the customers and provides data on them, such as type, value, length of contract, service requests, technical assistance, etc. Ultimately, all customer data are in the system and developers use them according to the activities, the position and the type of action they perform. The use of the system is effective while it is accessible to employees; Bretzke (2000) says this is a strategy in the globalized economy where individual relationships with customers are critical to the survival of the organizations.

Respondents were asked about how frequently the company uses the customer's relationship data, and the answers were:

V2 - At all times, it is very difficult to think of developing new solutions without thinking of the customers, today we are very much geared to anticipate customer needs to maintain the current and conquer new ones.

G2 - Our vision is that CRM customizes customer services, so it is used daily; everything that is done depends on the access to the system.

S3 - Everyday, in any action that you are going to make you need to extract some information about the customers whether it is a technical analysis for system expansion, or seeking their whole technical history. At the time to do a maintenance contract you have to check additives, all information that is there is used daily.

The relationship tool is used daily, as described above, the company works with 
customized products and services that require a good customer database which is used daily in all actions related to them.

The media used in relationship with customers are:

V2 - We have direct channels, such as e-mail, phone service, and voip. We also go to fairs, send materials by post, and other ways of communication, like MSN, and the important thing is to maintain communication with the customer.

D3 - We use e-mail, phone, contracts go by mail, chat, and voip.

G3 - Miscellaneous, voip, email, phone, and direct contact.

S3 - There are several types, I use the telephone, email, and voip.

This question sought to understand what happens to communication with customers to understand if there is an effective use of CRM and concluded that the company uses various channels for direct contact with the customer, which is something very positive, according to the concept of Swift (2001), who suggests that the company should have as an objective to increase the opportunities of direct access with the customers.

Respondents were asked if the company believes that the tool provides competitive advantage and we got the following answers:

V3 - We would not have different services we if we did not have TICO; it helps a lot to provide distinctive services to customers, which is a super advantage.

D2 - No doubt, TICO is very useful for customer care, and when we take good care of the customer it is possible to gain competitive advantages.

G2 -The system gives us an advantage as it allows us to make customers become loyal through personalized and distinctive attention.

S3 - I think so, because with the information that TICO provides we are able to do a lot, so if well used we can get some advantages.

In relation to the use of the CRM tool for a competitive advantage in the marketplace, most respondents stated: "Yes, the tool provides a competitive advantage, because it allows us to have a personalized and distinctive customer who generates a good competitive advantage in today's fierce competition.

Seeking to meet the first objective of "understanding the use of CRM in the customer relationship management processes", we realize that the studied company's information technology uses the concept of Bretzke (2000), where the individual relationship with customers is a priority. The company has developed a system that meets the recommendations of Kotler and Keller (2006), where CRM is the management of information about each customer, and of Scott (2001), who states that CRM involves capturing customer data throughout the enterprise.

By the results of the interviews it can be said that the company uses, according to Peppers and Rogers (2001), the operational CRM, since inside TICO all data about 
customers are stored (contract type, payment services, SSC or SAT) as well as collaborative CRM, because it is used by professionals who have contact with the customer (via telephone, e-mail, fax, among others). In general, one observes the use of TICO as a fundamental tool for customer services as the company develops customized products and services, and is also being used frequently by employees who serve customers.

To meet the second goal of the study that consists of "checking if the CRM data are transformed into knowledge," we asked if the data obtained in the CRM tool are shared by all sectors of the company; they replied:

V4 - In TICO there is customer data; the sharing of data depends on the access to and processing capacity to obtain knowledge from data system.

G3 - TICO is used by all sectors, but by levels of access through login and password, the commercial sector, for example, can see everything, but production cannot see the price of the equipment. So for each manager and for each employee there are levels of access.

S3 - Yes, all people have access to the system, but they rely on the login and password to know what type of access.

Unanimously all respondents said that developers have access to the system, to different levels of access depending on the position and the function they perform, what allows us to infer evidences of practice of knowledge management practices in the enterprise, which is, according to Borghoff and Pareschi (1998) and Von Krogh, Ichijō, and Nonaka (2001), the transformation of information into knowledge through a social and human process.

When enquired about the main shared data:

V3 - Each employee uses a type of data, for example, customer service; the SAC (Costumer Service) has access to all customer information which allows it to provide a distincitve and personalized service because they know the whole history (...)

G1 - It depends, everybody shares it by access levels, and even when someone does not have access to certain information, this will require a justification of the service manager.

S1- All data are in the system, when you do not have the information in the system I will get it from the people. Or when I do not have access to that information or I do not know where the information is, because today within our system everything is there as long as you know how to navigate and obviously have a login and password for access to do so $(\ldots)$

Access to the data happens in different ways according to the perception of the respondents; each person has an access type defined by the login and password. Supported by Ruggles (1998), for whom "share is transferring existing knowledge to other parts of the Organization", we can say that the company shares knowledge, because the financial team has access to quantity and incoming calls recorded in SSC or SAT and this knowledge is necessary for granting or not a financial benefit in the monthly fee, for example. 
100 Toriani, S., Angeloni, M. T.

When respondents were asked if the data of the CRM tool is transformed into information and knowledge:

V2 - We use many data to generate information and knowledge for decision making; they are very useful and necessary for the administration.

D1 - My team does it, not as it should, but it does it ... There is information that could be better used to have knowledge.

S3 - It varies from person to person, each has a goal with TICO's data, for example, I need to have information, but I don't know if others do it too.

In the enterprise, people have access to data, but the transformation of data into information and knowledge depends on each person, this is the assertion of most of the respondents, and this agrees with Tanaka (2000) and Stenmark (2001), for whom the knowledge always originates in people; without them the data is just data, without the processing there is no information and no knowledge. It was also noted that some of the respondents know the difference between data, information and knowledge, and for some vice-presidents and directors it would be the ideal if all the employees could use the tool to generate information and knowledge.

When respondents were asked about how the system data are used:

D1 - Here we use the data to meet the clients needs.

G2 - In my case, for example, that I take care of important customers, and since I am strategic, I use a lot of data from TICO, although I have a lot of tacit knowledge I also use the explicit one from the system.

G2 - I think that, in most cases, to meet the customer's needs and even to analyze the data for decision-making, because everything we need we take from the system, but I also think that there are a lot of things that are only in people's heads.

S1 - We use it for everything that you may think regarding customer service, all the data about the customer are in the system.

About the use of data, it is clear in the respondents' answers that each person uses the system their own way depending on the position and the activities they carry out. The interviews allowed us to realize the diverse uses; while vice presidents and directors use data for result analysis, managers and supervisors use data to serve customers.

When respondents were asked if the company has a knowledge management program:

V2 - Knowledge management has always existed here, for we sell knowledge indirectly, our solutions require knowledge, so we have a good knowledge management that is normally because of the professionals who work here.

V4 - This is still new to us with that name, but how to sell knowledge indirectly I believe that we have used knowledge management to maintain the business growth.

D2- Knowledge management is one of the toughest terms you can conceptualize. We do 
knowledge management, but tacit knowledge is a reality in parts, we are trying to improve the structure, the knowledge we have structured is available to all levels within the company, i.e. it is explicit.

S3 - (...) now we're waking up to this, we have a lot of information, but I don't know if it is applied as it should, you understand, but I believe so, I believe, although the company is very dynamic, so that part of management must be very well crafted here.

To answer if the company has a knowledge management program, we rescued the Nonaka and Takeuchi (1997) concept, in which Knowledge Management lies in the ability to relate information and apply it by the people in the company. According to this concept, there is evidence that the company works with Knowledge Management, maybe not the way initiated by some contributors, but essentially they have processes that allow relating the information and applying it, which to Davenport and Prusak (1998) originates in documents, routines, processes, and organizational practices.

Meeting the second specific objective, to "check if the CRM data are transformed into knowledge", we can say that the Information Technology Company uses a model of Knowledge Management. For Linde (2000), knowledge means nothing unless you know how to keep it, administer it and use it on a daily basis in the organization. Daily practices as well as data storage and administration for the knowledge generation have been identified in the studied company, but supported by Wah (2000), Dhaliwal and Benbasat (1996), and Easterby-Smith and Lyles (2005), we infer that the choice was by the technological way of gathering, capturing and storaging customer's data through a system enabled to meet the company's needs.

The third specific objective "seeks to identify if the strategic actions developed by the companies are based on the data from CRM."

When respondents asked if the CRM data are used in the construction of strategic planning, the following answers were given:

V1 - We use it for planning, whenever we need information we access the TICO system, we have filters on the database to stratify the data to strategically use the information.

V3 -They are fundamental to the definition of strategies and for performance monitoring.

D1 - We use some data to make the planning of this Board.

D3 - Yes, we use a lot of data to define new actions.

G3 - Yes, TICO's data are used for the preparation of planning, we do different analyses from those data.

S2 - I know that someone does this, but I do not know who or how.

The responses show that the people involved directly in the construction of strategic planning use the TICO tool to define strategic actions. On a supervisory level, as they do not participate directly in the planning, there are some questions about the use. This statement regarding supervisors was only possible after the answers were given about the Company dynamic construction of strategic planning. 
V1 - We do the planning annually, each year has a new planning.

D1 - This board makes its plan once a year.

G1 - We do it annually.

G3 - The Company does not have the culture to make a long-term strategic planning. We consider the fact that product that it works with is a technological product and that we never can predict what will happen in 4 or 5 years. Our planning is annual.

When respondents were questioned about who participates in the making of the strategic planning, these are the answers we got.

V1-First comes the planning of each Board with their data, and then the Vice Presidents make the planning for the company.

V3- First, each sector does it individually, then, we finish focusing on the company objectives.

D1-I call the managers and we do it together.

D3-Each sector makes a preview, but we are the ones who finish it. the President.

G1-We help the Board, but the end is done by the vice-presidents together with

G2-Managers together with directors make the planning that is forwarded to the vicepresidents and to the President.

S3-As far as I know it goes the managers and directors and then it goes to the vice-presidents.

Strategic planning involves the participation of managers and directors. The strategic planning is reviewed and finalized by the Vice-Presidents and directors. The same strategic planning is implemented top-down as well as decisions that are taken in the same way in the Company. It is a model used by several companies, but questioned when considering that there is the participation of operational and tactical levels for greater commitment in the implementation.

As for the manner the strategic planning is structured, we got the following answers.

V3-For instance, we want to grow in 2009, so we look at what happened in 2008 to define the strategies to achieve the goals of the year.

V4-each sector makes a pre-strategic planning and we finish it.

D1-once we do it, we forward it to the Vice President who makes the planning for the entire company along with the other vice-presidents and the President.

G1-Each Board has to make their own strategic planning and then the President and the Vice-Presidents define the strategic planning of the company.

When respondents were asked about the importance of the CRM tool for developing strategies the answers were:

V3-I consider TICO crucial because with the increase in competitiveness in all sectors 
there are no more products or solutions that are unique, you have to do better management of the sales force and of needs that the customer may have and the decisions they may make (...).

D1-On the basis of our type of product the customer database is critical to make strategic actions.

G1-our system has very important data about customers, and I think it's important to decide the company's strategies.

The interviews show that the company has a customer relationship software application with lots of data and information, and that it considers of utmost importance the data use for the making of the strategy. This is seen as ideal by Teixeira (2003) and Kotler \& Armstrong (2007).

When respondents were asked if CRM is used as a knowledge management strategy in the relationship with the customer, the following answers were given:

V1-we use TICO to generate knowledge and act ... When everyone knows that a contract is coming in and everybody goes to the customer and proposes the replacement of certain equipment, we upgrade (....) the TICO system e-mails and warns the seller to talk with the customer.

D2-I think that increasingly, now that this tends to intensify a lot, we do not explore all the available potential (...)

G3-Actually TICO (company's own application) is much more of a system to assist in customer relationship (....) but I do not know if it is used effectively to generate new knowledge and act strategically in the relationship with the customer

S1-I think that we still do not use all the system information to generate knowledge and relate better with the customer.

Some respondents argue that CRM is used as a knowledge management strategy, while others argue that we need to improve the practices of TICO use to generate knowledge and use it effectively in their relationship with the customer.

The third objective "seeks to identify if the strategic actions developed by the companies are based on the data from CRM" we realize that the studied company uses the customer's database to define strategies. According to Mckenna (1993), this Company's behavior is considered ideal in globalised markets in which organizations must act strategically and develop lasting relationships with customers. According to the respondents, the company currently has a good participation in its business segment, and it is the largest Brazilian company in its type of industry. It has a portfolio of customers, in which $70 \%$ of them have long-term contracts, continues in constant updating to stay in the current position in Brazil and seeks new markets.

\section{FINAL CONSIDERATIONS}


104 Toriani, S., Angeloni, M. T.

To study the use of CRM is to understand the importance of effective care and zeal for the customer. Such a statement was for too long just a "nice" speech in most companies, but it can be perceived as something applicable in the case study conducted in the Information Technology Company.

The first of the specific objectives of this study, "understanding the use of CRM in customer management processes" demonstrated that CRM helps the company to have distinctive services for their customers, providing personalized and interactive relationships that can provide security and credibility in relation to it. To support the development of its organizational activities, the company developed a technological tool that meets its needs.

The studied company follows the teachings of Richers (2000), Gummesson (2010), and Scott (2001), who claim that CRM should be regarded as a business strategy focused on understanding and anticipating the needs of current and potential customers and should be designed to increase the profitability and the level of satisfaction of those who use the goods and services marketed by the Company; and from Peppers and Rogers (2001): when the focus is on the customer, each customer is unique, so, all the communication is two-way and individual. In the Company, the dialogue is developed bilaterally and customers are treated in different ways.

The second objective of the study, to "check if the CRM data are transformed into knowledge", demonstrated the suitability of the company's practices in relation to the proposition made by authors Dhaliwal and Benbasat (1996), Gregor and Benbasat (1999), Zhao, Kumar, and Stohr (2001), that deal with knowledge management in the functionalist perspective. Among the ideal practices, the fact that all employees have access to the system is found; it provides data in a structured and organized manner, which facilitates the access of users, who can transform data into information and knowledge. The company uses tacit and explicit knowledge, although it is still possible to improve the practices with regard to the clarification of the strategic knowledge. Regarding the conversion of knowledge, according to Nonaka and Takeuchi (1997), the company works with four modes: socialization, externalization, internalization, and combination; however, it was evident in the interviews that the most commonly used modes are the externalization (tacit/explicit) and combination (explicit/explicit), concurring on the assumptions of Rodriguez y Rodriguez (2002).

The third goal, "sought to identify whether the strategic actions developed by the companies are based on the data from CRM." The result of data analysis demonstrates that the studied company's structure and strategic planning are based on data of TICO. It was noticed that among its strategic objectives maintaining existing customers is included, which requires the effective use of customer data for personalized service, providing a differentiator for the company. The focus is on the customer and not only on the speech common to most companies, translated by daily actions and by technological and human investments that enable services that delight and make the customers loyal.

About the overall objective of analyzing the role of CRM as support knowledge management and developing strategies of customer relationships in an Information Technology Company from Florianópolis, it is concluded that the company: (1) has an 
excellent customer data management system supported by an appropriate technological tool and developed to meet the needs of the Company, and that ensures the use of data daily with customer contact; (2) it works with a model of knowledge management, it has a technology base and resourceful persons qualified for the conversion of knowledge; (3) it uses the data from TICO to define strategies for customer relationship and performance assessment.

We can observe in the company the change from the era of effectiveness (focus on result) to the era of efficiency, i.e. concern geared not only to the satisfaction of needs, but rather the concern focused on overcoming the expectations of customers, seeking to make them loyal in relations of partnership and reciprocity. It is just not good enough for the customer to be faithful; it requires that the companies also be loyal to the customers both interms of goal and sale promises. This "partnership" relationship is only valid when it is good for both parties, because satisfied costumers are synonymous with good results for the company. The needs and expectations of customers and enterprises often are not common; each of them search for results, growth, profitability, and distinct solutions. The appropriation of technology coupled with the human differential provides gains in several aspects, such as cost reduction, agility in services, and proper data management to optimize resources and maximize customer relationship through interconnection.

As a general conclusion we emphasize that the studied company is a good example of CRM use to support Knowledge Management and to develop strategies of relationship with the customer, but some actions are recommended to maximize the use of the CRM tool for strategic management of the company's organizational knowledge of Information Technology study including (1) the deployment of Business Intelligence to make better use of the TICO data and facilitate the generation of information and knowledge, which could facilitate the use of the resource that is already stored in the system, but that is currently manhandled in the company; (2) conducting trainings focused on activities geared to the generation of new knowledge and sharing of information and knowledge between employees of the company and between them and their customers; (3) more effective involvement of tactical levels in building strategic planning, pursuing engagement and commitment in the strategic planning implementation.

The number of interviews made is considered as the limit of the study and the qualitative research prevents the results here recorded from extrapolating to the universe of Brazilian companies, even those in the sector of Information Technology. Therefore, it is recommended that a survey in Brazilian Information Technology be done on the use of CRM to support Knowledge Management and on the development of strategies for customer relationship.

\section{REFERENCES}

Alvarenga Neto, R.C.D. de. Gestão do conhecimento no Centro de Tecnologia Canavieira. In Angeloni, M.T. Gestão do conhecimento no Brasil: casos, experiências e 
práticas de empresas privadas. Rio de Janeiro: Qualitymark, 2010.

Bardin, L. Análise de Conteúdo. Lisboa. Edições 70, 1979.

Boone, L. E., Kurtz, D. L. Marketing Contemporâneo. Rio de Janeiro: LTC. 1998.

Borghoff, U. M; Pareschi, R. Information technology for knowledge management. Berlim: Springer, 1998.

Bretzke, M. O Marketing de Relacionamento e competição em tempo real. São Paulo: Atlas. 2000.

Cassapo, F. Gestão do conhecimento e transformação dos modelos de gestão - um retrato das experiências do Grupo Votorantim. In ANGELONI, M.T. Gestão do conhecimento no Brasil: casos, experiências e práticas de empresas privadas. Rio de Janeiro: Qualitymark, 2010.

Cruz, T. Workflow em sistemas de gerenciamento eletrônico de imagens. São Paulo: Atlas, 1998.

D'angelo, A. C.; Schneider, H.; Laran, J. A. Marketing de relacionamento junto a consumidores finais: um estudo exploratório com grandes empresas brasileiras. Revista de Administração Contemporânea [online], vol.10, n.1, pp. 73-93, 2006.

Davenport, T.; Prusak, L. Conhecimento empresarial: como as organizações gerenciam o seu capital intelectual. Rio de Janeiro: Campus, 1998.

Dhaliwal, J.; Benbasat, I. The use and effects of knowledge-based system explanations: theoretical foundations and a framework for empirical evaluation. Information Systems Research, v.7, p.243-361, 1996.

Dias, Sérgio Roberto (Coord). Gestão de marketing. São Paulo: Saraiva, 2003.

Easterby-Smith, M.; Lyles, M. Introduction: Watersheds of organizational learning and knowledge management. In: Easterby-Smith, M.; Lyles, M. (eds). Handbook of Organizational Learning and Knowledge Management. Malden: Blackwell, p.1-15, 2005.

Felisoni, C. D. A. Marketing de Relacionamento no Varejo. São Paulo: Saint Paul, 2004. $160 \mathrm{p}$.

Franco, C. Avaliação, ciclos e promoção na educação. Porto alegre: ARTMED, 1986. p 172.

George, J.F.; Iacono, S.; Kling, R. Learning in context: extensively computerized work groups as communities of practice. Accounting, Management and Information Techgnologies, v.5, p.185-202, 1995.

Godoy, A. S. Pesquisa qualitativa: tipos fundamentais. Revista de Administração de Empresas. São Paulo. V.35, n.3, (p.20-29, 1995).

Gregor, S.; Benbasat, I. Explanations form intelligent systems: theoretical foundations and implications for practice. MIS Quarterly, v.23, p.497-530, 1999.

Gummesson, E. Marketing de relacionamento total. Porto Alegre: Bookmann. 2010.

Hansen, M.; Nohria, N.;Tierney, T. What's your strategy for managing knowledge. 
Harvard Business Review. Harvard, vol.77 (p. 106-116, mar./abr. 1999.)

Kotler F; Keller, K. L. Administração de marketing. São Paulo: Pearson Prentice Hall, 2006.

Kotler, P.; Armstrong, G. Princípios de Marketing. São Paulo: Pearson Prentice Hall, 2007.

Lovelock, C. Serviços Marketing e Gestão. São Paulo: Saraiva, 2005

MCKENNA, R. Marketing de relacionamento: estratégias bem sucedidas para a era do cliente. Rio de Janeiro: Campus, 1993.

Nonaka, I.; Takeuchi, H. Criação de conhecimento na empresa: como as empresas geram a dinâmica da organização. Rio de Janeiro: Campus, 1997.

Nonaka, I; Konno, N. The concept of "Ba": building a foundation for knowledge creation. California Management Review, v. 40, n. 3, p. 40-41, 1998.

Norris, G.; Hurley, J. e-Business e ERP: transformando as organizações. Rio de Janeiro: Qualitymark. 2001

Peppers and Rogers Group do Brasil. CRM Series - Marketing 1 to 1. Um Guia executivo para entender e implantar estratégias de customer relationship management. São Paulo, 2000.

CRM Series - Marketing 1 to 1.São Paulo: Makron Books, 2001.

Polanyi, M. The tacit dimension. Londres: Routledge \& Kegan Paul, 1998.

Rapp, S.; Collins T. E. $5^{\text {a }}$ geração do marketing: maximarketing II, o segredo para alcançar o objetivo maior do marketing: a fidelização da clientela. São Paulo: McGraw Will, 1991.

Richardson, J. R. Pesquisa social: métodos e técnicas. São Paulo: Atlas, 1989.

Richers, R. Marketing: uma visão brasileira. São Paulo: Negócio, 2000.

Rodriguez y Rodriguez, M. V. Gestão do conhecimento nas empresas. Rio de Janeiro: E-papers Serviços Editoriais, 2002.

Ruggles, R. The state of the notion. California Management Review. Berkeley, v. 40, n. 3, (p. 80-89, primavera 1998).

Schultze, U.; Boland Jr., R.J. Knowledge management technology and the reproduction of knowledge work practices. Journal of Strategic Information Systems, v.9, p.193-212, 2000 .

Schultz, D. E.; Tannenbaum, S. I.; Lauterborn, Robert F. O novo paradigma do marketing: como obter resultados mensuráveis através do uso do database e das comunicações integradas de marketing. São Paulo: Makron Books, 1994.

Scott, N. "Gartner's CRM Vision: A roadmap for a customer - centric tranformation". The Gartner Group CRM. Summit 2001, 19 mar. 2001.2.

Sellitz, C.et al. Métodos de pesquisas nas relações sociais. São Paulo: EPU, 1987 2V 
108 Toriani, S., Angeloni, M. T.

Smit,J.; Talamo, M.F. Da impropriedade acadêmica de usar o termo gestão do conhecimento na opinião dos programas de Ciências da Informação. Revista de Ciência da Informação. V.3 n.5, out. 2007.

Stenmark, D. Leveraging tacit organizational knowledge. Journal of Management Information Systems, v.17, p.9-24, 2001.

Stone, M.; Woodcock, N; Machtynger, L. CRM Marketing de relacionamento com os cliente. São Paulo: Futura, 2001.

Sveiby, K. E. A nova riqueza das organizações. Rio de Janeiro: Campus, 1998.

Swift, R. CRM Customer Relationship Management. O Revolucionário Marketing de Relacionamento com o cliente. Rio de Janeiro: Campus, 2001.

Tanaka, I. Gestão do Conhecimento. Rio de Janeiro: Campus, 2000.

Teixeira, D.R. Gestão do Conhecimento nas Tecnologias de CRM. São Paulo: Edge Group, 2003.

Toffler, A. A terceira onda. Rio de Janeiro: Record, 1980.

Vera, D.; Crossan, M. Organizational learning and knowledge management: toward na integrative framework. In: Easterby-Smith, M.; Lyles, M. (eds). Handbook of Organizational Learning and Knowledge Management. Malden: Blackwell, p. 122-141, 2005.

Von Krogh, G.; Ichijo, K.; Nonaka, I. Facilitando a criação de conhecimento. Rio de Janeiro: Campus, 2001.

Wiig, Karl M. Integrating intellectual capital and knowledge management. Long Range Planning, v. 30, n. 3, p. 399-405, 1997.

Wah, L. Muito além de um modismo. HSM Management. Barueri, vol. 22, ano 4, (p. 52-64, set./out. 2000).

Zenone, L.C. Marketing de relacionamento- tecnologia, processos e pessoas. São Paulo: Atlas. 2010.

Zhao, J.L.; Kumar, A.; Stohr, E.A. Workflow-centric information distribution through e-mail. Journal of Management Information Systems, v.17, p.45-72, 2001. 